\title{
Improvement in Power Efficiency in Organic Light Emitting Diodes Through Intermediate Mg:Ag Layer in LiF/Mg:Ag/Al Cathodes
}

\author{
Sung Hyun Kim, ${ }^{a}$ Jyongsik Jang, ${ }^{a}$ and Jun Yeob Lee ${ }^{\text {b,z }}$ \\ ${ }^{a}$ School of Chemical and Biological Engineering, Seoul National University, Shinlim-dong, Kwanak-gu, \\ Seoul 151-742, Republic of Korea \\ ${ }^{b}$ Department of Polymer Science and Engineering, Dankook University, Hannam-dong, Yongsan-gu, \\ Seoul 140-714, Republic of Korea
}

Effects of $\mathrm{Mg}: \mathrm{Ag}$ interlayer between $\mathrm{LiF}$ and $\mathrm{Al}$ on electron injection and device performances of organic light-emitting diodes (OLEDs) were investigated. Thickness of $\mathrm{Mg}: \mathrm{Ag}$ layer was changed from 0 to $10 \mathrm{~nm}$ and the relationship between interlayer thickness and device performances was studied. Current density of OLEDs was increased due to efficient electron injection from cathode to organic layer by $\mathrm{Mg}: \mathrm{Ag}$ interlayer. In addition, power efficiency of OLEDs was improved by more than $50 \%$ due to low driving voltage and high recombination efficiency and it showed a maximum value at a $\mathrm{Mg}: \mathrm{Ag}$ thickness of $1.0 \mathrm{~nm}$. (C) 2007 The Electrochemical Society. [DOI: 10.1149/1.2756337] All rights reserved.

Manuscript submitted May 17, 2007; revised manuscript received June 15, 2007. Available electronically July $19,2007$.

Organic light-emitting diodes (OLEDs) have been developed for more than 20 years and have been used as displays for mobile phones, digital still cameras, and so on. However, lifetime and power consumption of OLEDs need to be improved further to expand their application to middle and large size displays.

Power consumption of OLEDs depends on light-emitting efficiency and driving voltage of OLEDs and low driving voltage is required to get low power consumption in OLEDs. There have been many studies to get low driving voltage in OLEDs and many studies focused on enhancing electron injection from electrodes to organic layer. ${ }^{1-5}$ Hung et al. reported enhanced electron injection from cathode to tris (8-hydroxyquinoline) aluminium $\left(\mathrm{Alq}_{3}\right)$ by using $\mathrm{LiF}$ as an electron injection layer. ${ }^{1}$ In other studies, it was found that electron injection barrier could be lowered by using $\mathrm{Li}_{2} \mathrm{O} / \mathrm{Al}$ as an electrode ${ }^{2}$ and $\mathrm{Mg}: \mathrm{Ag}$ was also effective to reduce driving voltage of OLEDs. ${ }^{3} \mathrm{LiF} / \mathrm{Ca} / \mathrm{Al}$ cathode system also gave low driving voltage and $\mathrm{CsF} / \mathrm{Ca} / \mathrm{Al}$ was very effective as a cathode due to efficient dissociation of $\mathrm{CsF}^{4}$ Recently, $\mathrm{NaCl} / \mathrm{Ca} / \mathrm{Al}$ was also used as a cathode for OLEDs and power efficiency could be improved by more than $30 \%$ compared with a common LiF/Al cathode. ${ }^{5}$ However, there was no systematic study about the effect of reactive metal thickness on device performance and no report about using $\mathrm{Mg}$ instead of $\mathrm{Ca}$ as an interlayer between $\mathrm{LiF}$ and $\mathrm{Al}$.

In this work, a cathode system of $\mathrm{LiF} / \mathrm{Mg}: \mathrm{Ag} / \mathrm{Al}$ was developed and its device performance was compared with that of conventional $\mathrm{LiF} / \mathrm{Al}$ cathode. The thickness of $\mathrm{Mg}: \mathrm{Ag}$ was controlled and device performances of $\mathrm{LiF} / \mathrm{Mg}: \mathrm{Ag} / \mathrm{Al}$ devices were correlated with cathode structure. In particular, the effect of $\mathrm{Mg}$ thickness on device performance was studied in detail and electron injection mechanism of $\mathrm{LiF} / \mathrm{Mg}: \mathrm{Ag} / \mathrm{Al}$ was discussed.

\section{Experimental}

A device configuration of indium tin oxide $/ N, N^{\prime}$-diphenyl$N, N^{\prime}$-bis-[4-(phenyl- $m$-totyl-amino)-phenyl]-biphenyl-4,4' -diamine $(60 \mathrm{~nm}) / N, N^{\prime}-\operatorname{di}\left(1\right.$-naphthyl) $N, N^{\prime}$-diphenylbenzidine $(30 \mathrm{~nm}) /$ $\mathrm{Alq}_{3}(50 \mathrm{~nm}) / \mathrm{LiF}(1 \mathrm{~nm}) / \mathrm{Mg}: \operatorname{Ag}(x \mathrm{~nm}) / \operatorname{Al}(100 \mathrm{~nm})$ was used to study the effect of $\mathrm{Mg}: \mathrm{Ag}$ thickness on device performances. The thickness of $\mathrm{Mg}: \mathrm{Ag}$ was controlled from 0 to $10 \mathrm{~nm}$ to correlate $\mathrm{Mg}: \mathrm{Ag}$ thickness with device performances. Electron only devices with a device configuration of $\mathrm{Al} / \mathrm{Alq}_{3}(100 \mathrm{~nm}) / \mathrm{LiF} /$ $\mathrm{Mg}: \operatorname{Ag}(x \mathrm{~nm}) / \mathrm{Al}$ were also fabricated to understand electron injection performances of $\mathrm{LiF} / \mathrm{Mg}: \mathrm{Ag} / \mathrm{Al}$ compared with $\mathrm{LiF} / \mathrm{Al}$. Deposition rate of $\mathrm{Mg}: \mathrm{Ag}$ was $0.2 \AA / \mathrm{s}$ and $\mathrm{Al}$ was evaporated at a depo-

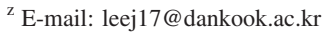

sition rate of $2 \AA /$ s. Current-voltage-luminance characteristics of electron only devices were measured with a Keithley 2400 and PR650 spectrophotometer (Photoresearch Inc.).

\section{Results and Discussion}

$\mathrm{LiF} / \mathrm{Al}$ has been used as a conventional cathode for small molecule OLEDs, but its electron injection to organic layer has to be improved to get low driving voltage. Electron injection mechanism of $\mathrm{LiF} / \mathrm{Al}$ cathode has not been clarified yet, but $\mathrm{LiF}$ dissociation and interface dipole formation are considered as dominant mechanisms for efficient electron injection. ${ }^{6} \mathrm{LiF}$ dissociation by metal deposition is thermally activated and it was reported that reactive metals such as $\mathrm{Ca}$ could have high chemical reactivity with LiF, generating $\mathrm{Li}$ ion in organic layer. ${ }^{4}$ Therefore, thin $\mathrm{Mg}$ layer between $\mathrm{LiF}$ and $\mathrm{Al}$ can facilitate dissociation of $\mathrm{LiF}$ due to high chemical reactivity of $\mathrm{Mg}$ and chemical reaction of $\mathrm{Mg}$ with $\mathrm{LiF}$ can be activated by $\mathrm{Al}$ deposition. In this work, $\mathrm{Mg}$ : $\mathrm{Ag}$ was used as an interlayer instead of $\mathrm{Mg}$ because $\mathrm{Mg}$ cannot be effectively deposited on $\mathrm{Alq}_{3}$.

Figure 1 shows $I-V$ curves of $\mathrm{LiF} / \mathrm{Mg}: \mathrm{Ag} / \mathrm{Al}$ cathodes according to $\mathrm{Mg}: \mathrm{Ag}$ thicknesses. $\mathrm{Mg}: \mathrm{Ag}$ thickness was controlled from 0 to $10 \mathrm{~nm}$ to investigate the relationship between $\mathrm{Mg}: \mathrm{Ag}$ thickness and device performances of $\mathrm{LiF} / \mathrm{Mg}: \mathrm{Ag} / \mathrm{Al}$ devices. $\mathrm{LiF} / \mathrm{Mg}: \mathrm{Ag} / \mathrm{Al}$ devices showed the highest current density value at $\mathrm{Mg}: \mathrm{Ag}$ thickness of $0.5 \mathrm{~nm}$ and it was decreased at $\mathrm{Mg}: \mathrm{Ag}$ thickness over $3 \mathrm{~nm}$ even though the current density of all $\mathrm{LiF} / \mathrm{Mg}: \mathrm{Ag} / \mathrm{Al}$ devices was higher than that of $\mathrm{LiF} / \mathrm{Al}$ devices. The current density of

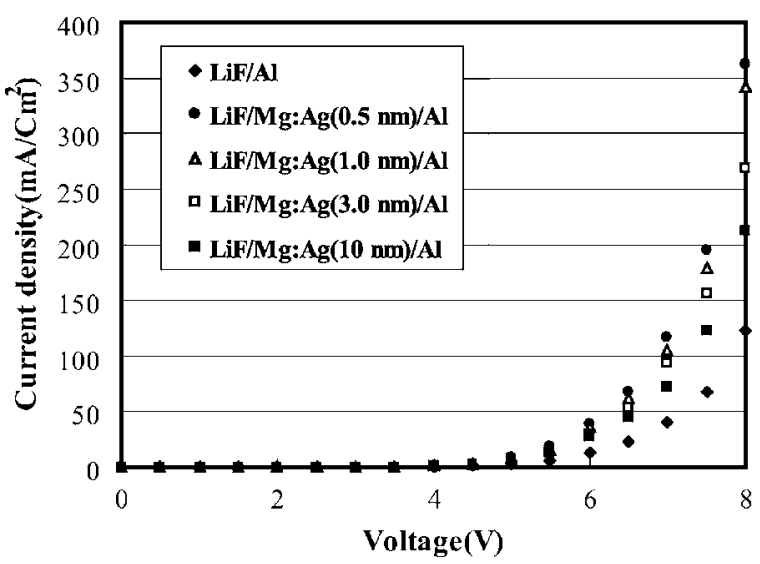

Figure 1. Current density-voltage curves of $\mathrm{LiF} / \mathrm{Mg}: \mathrm{Ag} / \mathrm{Al}$ devices according to $\mathrm{Mg}: \mathrm{Ag}$ thickness. 


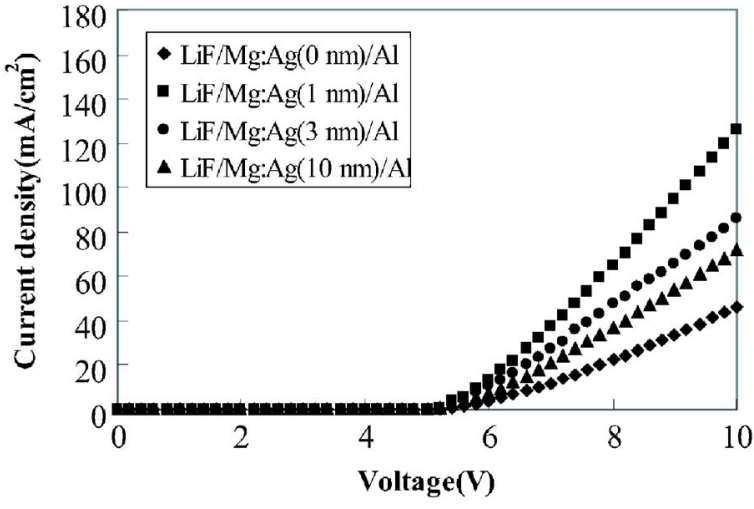

Figure 2. Current density-voltage curves of electron only devices of $\mathrm{LiF} / \mathrm{Mg}: \mathrm{Ag} / \mathrm{Al}$.

$\mathrm{LiF} / \mathrm{Mg}: \mathrm{Ag} / \mathrm{Al}$ with $0.5 \mathrm{~nm} \mathrm{Mg}: \mathrm{Ag}$ interlayer at $6 \mathrm{~V}$ was higher than that of LiF/Al by three times. The high current density in $\mathrm{LiF} / \mathrm{Mg}: \mathrm{Ag} / \mathrm{Al}$ devices can be explained by high chemical reactivity of $\mathrm{Mg}: \mathrm{Ag}$ with $\mathrm{LiF}$ compared with chemical reactivity of $\mathrm{Al}$ with LiF. Alkaline earth metals are known to have high chemical reactivity with alkaline halide and $\mathrm{Mg}$ can facilitate the dissociation of $\mathrm{LiF}$, resulting in efficient electron injection from cathode to $\mathrm{Alq}_{3}$. Assuming $\mathrm{LiF}$ dissociation by cathode metals, Gibbs free energy of formation for the $\mathrm{LiF}-\mathrm{Al}$ and $\mathrm{LiF}-\mathrm{Mg}$ can be calculated based on the reaction mechanism below ${ }^{7}$

$$
3 \mathrm{LiF}+\mathrm{Al}+3 \mathrm{Alq}_{3} \rightarrow 3 \mathrm{Li}^{+} \mathrm{Alq}_{3}^{-}+\mathrm{AlF}_{3} \quad \Delta G=-7.1 \mathrm{~kJ} / \mathrm{mol}
$$

$$
2 \mathrm{LiF}+\mathrm{Mg}+2 \mathrm{Alq}_{3} \rightarrow 2 \mathrm{Li}^{+} \mathrm{Alq}_{3}^{-}+\mathrm{MgF}_{2} \quad \Delta G=-121.8 \mathrm{~kJ} / \mathrm{mol}
$$

Negative Gibbs free energy for the reaction between $\mathrm{LiF}$ and $\mathrm{Mg}$ indicates that $\mathrm{LiF}$ is more reactive toward $\mathrm{Mg}$ rather than toward $\mathrm{Al}$ and $\mathrm{Li}$ formation can be effective in $\mathrm{LiF} / \mathrm{Mg}: \mathrm{Ag}$, explaining high current density in $\mathrm{LiF} / \mathrm{Mg}: \mathrm{Ag} / \mathrm{Al}$ devices. However, the increase of current density in the device with $0.5 \mathrm{~nm}$ thick $\mathrm{Mg}$ interlayer cannot be explained by just chemical reactivity of $\mathrm{Mg}$ or dipole effect. $\mathrm{LiF}$ dissociation by highly reactive $\mathrm{Mg}$ may be the same considering only chemical reactivity of $\mathrm{Mg}$ with $\mathrm{LiF}$ and interface dipole also will not be affected by $\mathrm{Mg}$ thickness because the interface dipole is influenced by the chemical nature of metal fluoride. However, in case of $\mathrm{LiF}$ and $\mathrm{MgF}_{2}$, its contribution to the interface dipole will not be affected by $\mathrm{Mg}$ thickness. One factor which can affect the chemical reaction between $\mathrm{Mg}$ and $\mathrm{LiF}$ in $\mathrm{LiF} / \mathrm{Mg}: \mathrm{Ag} / \mathrm{Al}$ is a thermal energy from $\mathrm{Al}$ deposition. There was a previous report that the current density of the $\mathrm{LiF} / \mathrm{Al}$ system depended greatly on temperature and high temperature was beneficial to liberate more $\mathrm{Li}$ by effective dissociation of $\mathrm{LiF}^{8}{ }^{8} \mathrm{In} \mathrm{LiF} / \mathrm{Mg}: \mathrm{Ag} / \mathrm{Al}$ devices, chemical reaction between $\mathrm{Mg}$ and $\mathrm{LiF}$ can be facilitated by thermal energy supplied from $\mathrm{Al}$ deposition because thermal energy has an effect of providing energy to overcome activation energy of the reaction. At low $\mathrm{Mg}$ :Ag thickness $(0.5 \mathrm{~nm}), \mathrm{Mg}$ cannot form a continuous film and both $\mathrm{LiF}$ and $\mathrm{Mg}$ are exposed to $\mathrm{Al}$ deposition. Therefore, $\mathrm{LiF}$ dissociation by chemical reaction of $\mathrm{LiF}$ and $\mathrm{Mg}$ can be activated by $\mathrm{Al}$ deposition. However, at high $\mathrm{Mg}: \mathrm{Ag}$ thickness $(>3 \mathrm{~nm}$ ), most of $\mathrm{LiF}$ would be covered with $\mathrm{Mg}: \mathrm{Ag}$ film and interfacial chemical reaction between $\mathrm{LiF}$ and $\mathrm{Mg}$ is difficult to be activated by $\mathrm{Al}$ deposition because $\mathrm{Al}$ cannot penetrate into the interfacial region. This is in agreement with the data that the current density of $\mathrm{LiF} / \mathrm{Mg}: \mathrm{Ag} / \mathrm{Al}$ device is saturated at a $\mathrm{Mg}$ thickness over $3 \mathrm{~nm}$.

To prove efficient electron injection by the $\mathrm{Mg}: \mathrm{Ag}$ interlayer, electron only devices were prepared and electron injection from cathode to $\mathrm{Alq}_{3}$ was compared. Figure 2 is a current density-voltage curve of electron only devices with $\mathrm{LiF} / \mathrm{Mg}: \mathrm{Ag} / \mathrm{Al}$ cathodes. Current density was high in electron only device with $1.0 \mathrm{~nm} \mathrm{Mg:Ag}$ interlayer, agreeing with the current density-voltage data of

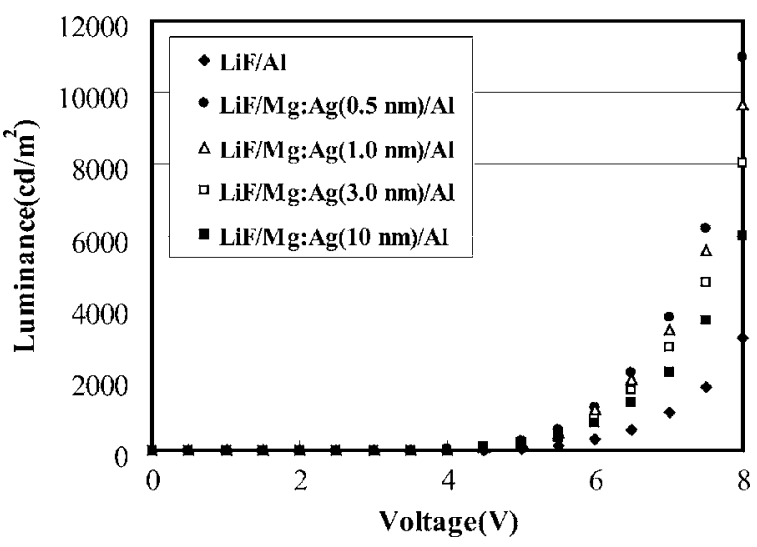

Figure 3. Luminance-voltage curves of $\mathrm{LiF} / \mathrm{Mg}: \mathrm{Ag} / \mathrm{Al}$ devices according to $\mathrm{Mg}: \mathrm{Ag}$ thickness.

$\mathrm{LiF} / \mathrm{Mg}: \mathrm{Ag} / \mathrm{Al}$ devices. This result indicates that the increase of current density in OLEDs with $\mathrm{Mg}: \mathrm{Ag}$ interlayer is due to enhanced electron injection from cathodes.

Luminance of $\mathrm{LiF} / \mathrm{Mg}: \mathrm{Ag} / \mathrm{Al}$ devices is shown in Fig. 3. As expected from current density-voltage curves, luminance of $\mathrm{LiF} / \mathrm{Mg}: \mathrm{Ag} / \mathrm{Al}$ devices was higher than that of LiF/Al. The luminance showed the same tendency as current density.

From the current density, voltage and luminance data of $\mathrm{LiF} / \mathrm{Mg}: \mathrm{Ag} / \mathrm{Al}$ devices, current efficiency and power efficiency of the devices were plotted against $\mathrm{Mg}: \mathrm{Ag}$ thickness (Fig. 4). There was 50\% improvement of power efficiency and power efficiency of $\mathrm{LiF} / \mathrm{Mg}: \mathrm{Ag} / \mathrm{Al}$ device with $1.0 \mathrm{~nm} \mathrm{Mg}: \mathrm{Ag}$ layer was $1.7 \mathrm{~lm} / \mathrm{W}$ compared with $1.1 \mathrm{~lm} / \mathrm{W}$ of $\mathrm{LiF} / \mathrm{Al}$ device. In general, power efficiency is determined by driving voltage and current efficiency of devices. In the $\mathrm{LiF} / \mathrm{Mg}: \mathrm{Ag} / \mathrm{Al}$ case, driving voltage was lowered by $1 \mathrm{~V}$ and current efficiency was enhanced from 2.6 to $3.2 \mathrm{~cd} / \mathrm{A}$, resulting in high power efficiency. The high current efficiency in $\mathrm{LiF} / \mathrm{Mg}: \mathrm{Ag} / \mathrm{Al}$ cathode system is due to efficient hole and electron recombination in the emitting layer. Efficient electron injection from cathode to emitting layer improves hole and electron balance because hole is the majority carrier in our device structure. The efficiency value was even higher than that of efficiency value reported in other work. ${ }^{9}$

\section{Conclusion}

Power efficiency of $\mathrm{LiF} / \mathrm{Mg}: \mathrm{Ag} / \mathrm{Al}$ devices was improved by $50 \%$ due to low driving voltage and high current efficiency. Electron injection from cathode to $\mathrm{Alq}_{3}$ layer was enhanced by $\mathrm{Mg}: \mathrm{Ag}$ interlayer and current injection was maximized at a $\mathrm{Mg}: \mathrm{Ag}$ thickness of $1 \mathrm{~nm}$.

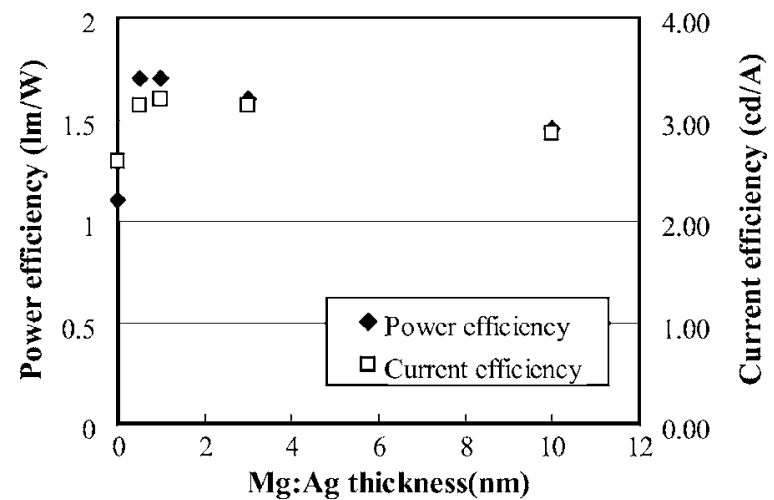

Figure 4. Current efficiency and power efficiency of $\mathrm{LiF} / \mathrm{Mg}: \mathrm{Ag} / \mathrm{Al}$ devices according to $\mathrm{Mg}: \mathrm{Ag}$ thickness. 


\section{References}

1. L. S. Hung, C. W. Tang, and M. G. Manson, Appl. Phys. Lett., 70, 152 (1997). 2. T. Wakimoto, Y. Fukuda, K. Nagayama, A. Yokoi, H. Nakada, and M. Tschuida, IEEE Trans. Electron Devices, 44, 1245 (1997).

3. C. O. Poon, F. L. Wong, S. W. Tong, R. Q. Zhang, C. S. Lee, and S. T. Lee, Appl. Phys. Lett., 83, 1038 (2003)

4. T. M. Brown, R. H. Friend, I. S. Millard, D. J. Lacey, T. Butler, J. H. Burroughes, and F. Cacialli, J. Appl. Phys., 93, 6159 (2003).
5. S. Shi and D. Ma, Appl. Surf. Sci., 252, 6337 (2006).

6. H. Heil, J. Steiger, S. Karg, M. Gastel, H. Ortner, H. von Seggern, and M. Stoßel, J. Appl. Phys., 89, 420 (2001).

7. M. G. Mason, C. W. Tang, L.-S. Hung, P. Raychaudhuri, J. Madathil, D. J. Giesen, L. Yan, Q. T. Le, Y. Gao, S.-T. Lee, et al., J. Appl. Phys., 89, 2756 (2001).

8. S. D. Wang, M. K. Fung, S. L. Lai, S. W. Tong, C. S. Lee, S. T. Lee, H. J. Zhang, and S. N. Bao, J. Appl. Phys., 94, 169 (2003).

9. J. Lee, Y. Park, D. Y. Kim, H. Y. Chu, H. Lee, and L.-M. Do, Appl. Phys. Lett., 82, 173 (2003). 